\title{
( The Impact of Liquidity Decision on Managerial aße Performance: Evidence from Private Commercial ResearchHouse Banks in Bangladesh
}

\section{Sumi Saha}

Assistant Professor, Department of Accounting and Information Systems (AIS), University of Rajshahi, Rajshahi-6205, BANGLADESH

\begin{abstract}
This study has examined the impact of liquidity decisions on the managerial performance of ten listed conventional private commercial banks. The required data have been collected from the five years' annual reports of the sample banks and analyzed through formulating different null hypotheses. Findings from the testing of null hypotheses with the use of the ANOVA technique reveal that there is no significant variation of different indicators of liquidity decision as well as the managerial performance of the sample banks. Findings are taken from conducting the multiple regression analysis with ordinary least square (OLS) model also indicate that the indicators of liquidity decision namely current ratio is positively and insignificantly associated with net profit ratio as well as return on equity but negatively and insignificantly associated with return on assets as well as return on investment. Moreover, the networking capital ratio as another indicator of liquidity decision is negatively and insignificantly associated with net profit ratio, return on assets as well as return on equity but positively and insignificantly associated with return on investment of the sample banks over the study period.
\end{abstract}

Keywords: Different indicators of liquidity decision, different indicators of managerial performance, conventional private commercial banks, Bangladesh

\section{INTRODUCTION}

The banking sector is the most growing and influential industry in the economy of Bangladesh. In most cases the banking industry supports the development aspect of an economy. In the competitive banking world, banks are surviving through enhancing their performance and efficiency. Bank's profitability depends on some internal and external factors. These factors act as agents to fluctuate the net earnings of a bank. Bank's ability to meet the depositors' demand within a short time is called liquidity which is essential to operate the regular banking process. (Parvin et. al., 2019). Liquidity management is a concept that is receiving serious attention all over the world especially with the current financial situations and the state of the world's economy. The concern of business owners and managers all over the world is to devise a strategy of managing their day to day operations in order to meet their obligations as they fall due and increase profitability and shareholder's wealth (Ware, 2015). Profitability refers to the net income where revenues exceed relevant expenses. Income is generated from the different ongoing central activities of corporate business and expense is cost of resources which are used to generate profit. Profitability is the main objective of any business and without profitability any business cannot survive in the market for the long run (Das et. al., 2015). Financial intermediation role of the commercial banks hence becomes the bed rock of the two major functions of commercial banks like deposit mobilization and credit extension. An adequate financial intermediation requires the purposeful attention of the bank management to profitability and liquidity, which are two conflicting goals of the commercial banks (Adebayo et. al., 2011).

Financial sector of Bangladesh consists of banks as well as non-banks financial institutions and banks play a significant role in the economic development of any country. In Bangladesh the healthy banking sector is one of the most essential parts of financial systems that help extend the overall economic development process. The main objective of banking sector is to receive public savings through different types of accounts for investment in the profitable sector to enrich the level of profitability of corporate business that ultimately leads to the better managerial performance. Commercial bank deals with money management for earning profit through providing different services to the customers as per requirement. 
Private commercial banks cover the larger portion of the banking sector in Bangladesh and more importantly financial sector that has a good position in sustainable economic development as well as economic growth of any nation. Basically the depositors are concerned about the liquidity situation of any corporate business for knowing the solvency position. Simultaneously, the depositors also are concerned to evaluate the trend of profitability. In this sense the liquidity and profitability are the two effective indicators of corporate business to display the sound performance but theoretically there is inverse relationship between liquidity and profitability because the excess investment in the form of liquidity leads to poor profitability. On the other hand, the lower investment in cash may result in small liquidity position. So, the proper liquidity management in banking sector is important to maximize the profit as well as the shareholder's wealth. In this study, an attempt has been made to evaluate the impact of liquidity on managerial performance.

The remaining part of the study has been designed under the different heads such as research objectives, research hypotheses, research methodology, research model, findings and discussion as well as conclusion and recommendations.

\section{Research Objectives}

The main objective of this study is to evaluate the impact of the different indicators of liquidity decision on managerial performance indicators and the specific objectives are:

- To analyze the variation of the different indicators of liquidity decision as well as managerial performance among the sample banks over the study period.

- To evaluate the impact of the different indicators of liquidity decision on the different indicators of managerial performance of the sample banks over the study period.

\section{Research Hypotheses}

In the light of the study objectives this research study has formulated and tested the following null hypotheses:

- Ho1: There is no significant variation of different indicators of liquidity decision as well as managerial performance of the sample banks over the study period.

- Ho2: There is no significant impact of different indicators of liquidity decision on the different indicators of managerial performance of the sample banks over the study period

\section{Research Methodology}

Sample Selection: With a view to achieving the objectives of this study considered only conventional private commercial banks in Bangladesh have been taken as sample out of total listed banks in Dhaka Stock Exchange
.This study has taken ten listed conventional private commercial banks namely Pubali Bank Limited, Uttara Bank Limited, National Bank Limited, AB Bank Limited, IFIC Bank Limited, Dutch Bangle Bank Limited, National Credit and Commerce Bank Limited, Preminer Bank Limited, One Bank Limited and Eastern Bank Limited through applying the judgmental sampling technique as well as based on the facility of required data collection.

Nature of Data: This present research study has utilized only secondary data that are mainly collected from the annual reports of the sample banks in the respective years from 2013 to 2017 for the purpose of the study.

Dependent and Independent Variables: In order to reveal the study findings this study has used two independent variable like current ratio and net working capital ratio as the indicators of liquidity decision. On the other hand, four dependent variables such as net profit ratio, return on assets, return on equity as well as return on investment have been used as the indicators of managerial performance.

Statistical Techniques: To analyze the collected data this study has employed the different parts of descriptive statistics namely mean, standard deviation, variance, minimum value and maximum value. This study has also employed the ANOVA technique as well as multiple regression analysis with ordinary least square (OLS) model through designing the different null hypotheses with the use of SPSS program.

\section{Research Model}

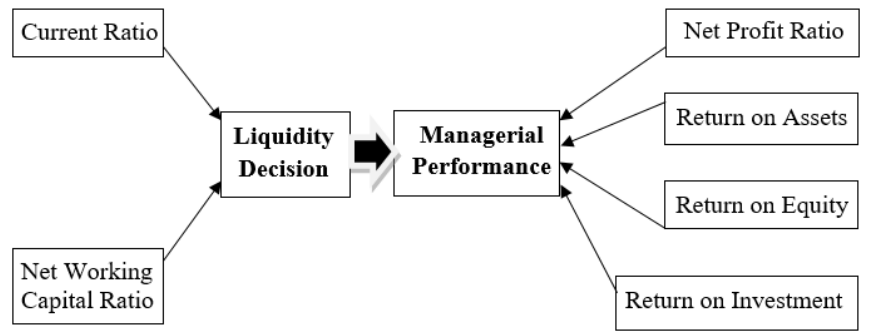

Source: Researcher's Own Preparation

\section{Findings AND DISCUSSION}

Analysis of the Results of Descriptive Statistics about the Different Variables

Table 1: The results of descriptive statistics

\begin{tabular}{|l|c|c|c|c|c|}
\hline \multicolumn{1}{|c|}{ Variables } & Minimum & Maximum & Mean & SD & Variance \\
\hline $\begin{array}{l}\text { Current } \\
\text { Ratio }\end{array}$ & 1.1100 & 2.8800 & 1.8244 & 0.4770 & 0.2276 \\
\hline $\begin{array}{l}\text { Net Working } \\
\text { Capital Ratio }\end{array}$ & 0.2800 & 0.9800 & 0.8630 & 0.1437 & 0.0207 \\
\hline Net Profit Ratio & 0.2900 & 34.1400 & 19.0602 & 6.2243 & 38.7419 \\
\hline Return on Assets & 0.0100 & 1.9000 & 1.0134 & 0.3678 & 0.1352 \\
\hline Return on Equity & 0.1300 & 20.5000 & 11.6244 & 3.8452 & 14.7857 \\
\hline $\begin{array}{l}\text { Return on } \\
\text { Investment }\end{array}$ & 1.6700 & 17.2600 & 9.4356 & 3.4354 & 11.8022 \\
\hline
\end{tabular}

Source: Analysis of Annual Reports of the Sample Banks 
This Table shows the outcomes of expository statistics about the different variables during the period of this study. The mean and standard deviation values of current ratio are 1.8244 and 0.4770 with minimum and maximum values of 1.1100 and 2.8800 percentages respectively. In addition, this Table exposes the mean value: 0.8630, standard deviation value: 0.1437 , minimum value: 0.2800 and maximum value of net working capital: 0.9800 . In terms of net profit ratio the mean value is 19.0602 percentages with standard deviation of 6.2243 percentages and the maximum value is 34.140 percentages with minimum value of 0.2900 percentages. Again the mean value is 1.0134 percentages, standard deviation is 0.3678 percentages, maximum value is 1.900 percentages as well as minimum value is 0.0100 percentages in case of return on assets. Moreover the mean value of return on equity shows 11.6244 percentages with standard deviation of 3.8452 percentages and the maximum value is 20.5000 percentages with minimum value of 0.1300 percentages. Furthermore, the mean and standard deviation values are 9.4356 and 3.4354 percentages respectively with the minimum and maximum values are 1.6700 and 17.2600 percentages respectively in terms of return on investment of the sample banks.

\section{ANALYSIS OF THE RESULTS OF ANOVA TECHNIQUES}

With a view to investigating the existence of significant variation among the different indicators of the liquidity decision as well as the managerial performance the ANOVA testing model has been developed with a null hypothesis Ho1: There is no significant variation of different indicators of liquidity decision as well as managerial performance of the sample banks over the study period and results in this regard are stated below:

Table 2: The Table is representing the results of ANOVA test

\begin{tabular}{|c|c|c|c|c|c|}
\hline \multicolumn{6}{|c|}{ Variable Name: Current Ratio } \\
\hline & Sum of Squares & $\mathrm{df}$ & Mean Square & F & Sig. \\
\hline Between Groups & 10.388 & 9 & 1.154 & 60.522 & 0.000 \\
\hline Within Groups & 0.763 & 40 & 0.019 & & \\
\hline Total & 11.151 & 49 & & & \\
\hline \multicolumn{6}{|c|}{ Variable Name: Net Working Capital Ratio } \\
\hline & Sum of Squares & $\mathrm{df}$ & Mean Square & $\mathrm{F}$ & Sig. \\
\hline Between Groups & 0.635 & 9 & 0.071 & 7.470 & 0.000 \\
\hline Within Groups & 0.378 & 40 & 0.009 & & \\
\hline Total & 1.012 & 49 & & & \\
\hline \multicolumn{6}{|c|}{ Variable Name: Net Profit Ratio } \\
\hline & Sum of Squares & $\mathrm{df}$ & Mean Square & $\mathrm{F}$ & Sig. \\
\hline Between Groups & 1275.453 & 9 & 141.717 & 9.100 & 0.000 \\
\hline Within Groups & 622.900 & 40 & 15.573 & & \\
\hline Total & 1898.353 & 49 & & & \\
\hline \multicolumn{6}{|c|}{ Variable Name: Return on Assets } \\
\hline & Sum of Squares & $\mathrm{df}$ & Mean Square & $\mathrm{F}$ & Sig. \\
\hline Between Groups & 4.001 & 9 & 0.445 & 6.772 & 0.000 \\
\hline Within Groups & 2.626 & 40 & 0.066 & & \\
\hline Total & 6.627 & 49 & & & \\
\hline \multicolumn{6}{|c|}{ Variable Name: Return on Equity } \\
\hline & Sum of Squares & $\mathrm{df}$ & Mean Square & $\mathrm{F}$ & Sig. \\
\hline Between Groups & 446.519 & 9 & 49.613 & 7.139 & 0.000 \\
\hline Within Groups & 277.979 & 40 & 6.949 & & \\
\hline Total & 724.499 & 49 & & & \\
\hline \multicolumn{6}{|c|}{ Variable Name: Return on Investment } \\
\hline & Sum of Squares & $\mathrm{df}$ & Mean Square & $\mathrm{F}$ & Sig. \\
\hline Between Groups & 401.579 & 9 & 44.620 & 10.099 & 0.000 \\
\hline Within Groups & 176.730 & 40 & 4.418 & & \\
\hline Total & 578.309 & 49 & & & \\
\hline
\end{tabular}

Source: Analysis of Annual Reports of the Sample Banks

The ANOVA test found that the $\mathrm{F}$ ratios of the different indicators of liquidity decision as well as managerial performance are significant at $5 \%$ level which means the null hypothesis is rejected. So, there is significant variation among the different indicators of liquidity decision as well as managerial performance of the sample banks.

\section{Results OF MulTiCOLLINEARITY StATISTICS}

It is important to check the existence of multicollinerity of the different independent variables before going to conduct the multiple regression analysis with respective ordinary least square (OLS) model and the results of multicollinearity in this regard are presented below. 
Table 3: The results of multicollinerity statistics

\begin{tabular}{|l|c|c|}
\hline \multicolumn{1}{|c|}{ Variables } & \multicolumn{2}{|c|}{ Collinerity Statistics } \\
\cline { 2 - 3 } & Tolerance & VIF \\
\hline Current Ratio (CR) & 0.859 & 1.164 \\
\cline { 2 - 3 } Net Working Capital Ratio (NWCR) & 0.859 & 1.164 \\
\hline
\end{tabular}

Source: Analysis of Annual Reports of the Sample Banks

This study has considered two independent variables like current ratio and net working capital ratio to conduct the multiple regression analysis with ordinary least square (OLS) model and the results report that the values of variance inflation factor (VIF) are lower than 10 and it confirms that the multicollinerity is not a problem in this regression model

\section{Discussion OF the Results of Multiple REGRESSION ANALYSIS}

To be informed about the existence of significant impact of the different indicators of liquidity decision on the managerial performance surrogated by net profit ratio, return on assets, return on equity and return on investment this study has conducted multiple regression analysis with ordinary least square (OLS) model using a null hypothesis Hoz: There is no significant impact of different indicators of liquidity decision on the different indicators of managerial performance of the sample banks and the results are:

MODEL ONE: NPR $=\alpha+\beta_{1}$ Current Ratio $+\beta_{2}$ Net Working Capital Ratio+ $\varepsilon$

In order to test whether the net profit ratio of the sample banks is influenced by the different indicators of liquidity decision such as current ratio as well as net working capital ratio this study has conducted multiple regression analysis with a null hypothesis of Ho2.1: There is no significant impact of the different indicators of liquidity decision on managerial performance represented by net profit ratio. The results are presented below:

Table 4: The outcomes of the model summary

\begin{tabular}{|c|c|c|c|c|c|c|c|c|c|}
\hline \multirow{2}{*}{ Model } & \multirow[b]{2}{*}{$\mathrm{R}$} & \multirow{2}{*}{$\begin{array}{c}\mathrm{R} \\
\text { Square }\end{array}$} & \multirow{2}{*}{$\begin{array}{l}\text { Adjusted } \\
\text { R Square } \\
\end{array}$} & \multirow{2}{*}{$\begin{array}{l}\text { Std. Error of } \\
\text { the Estimate }\end{array}$} & \multicolumn{5}{|c|}{ Change Statistics } \\
\hline & & & & & R Square Change & F Change & df1 & df2 & Sig. F Change \\
\hline 01 & 0.083 & 0.007 & -0.035 & 6.333 & 0.007 & 0.163 & 2 & 47 & 0.850 \\
\hline $\mathrm{a}$ & Predicto & onsta & WCR, CR & & & & & & \\
\hline
\end{tabular}

Source: Analysis of Annual Reports of Sample Banks

From the results of model summary it is evident that the value of $R$ square which is 0.007 that indicates the 0.7 percentage of the variability is the dependent variable like net profit ratio is explained by the independent variables like current ratio as well as net working capital ratio of the sample banks. In this case the null hypothesis is accepted which means there is no significant impact of the different indicators of liquidity decision on managerial performance as represented by net profit ratio.

Table 5: The outcomes of coefficients

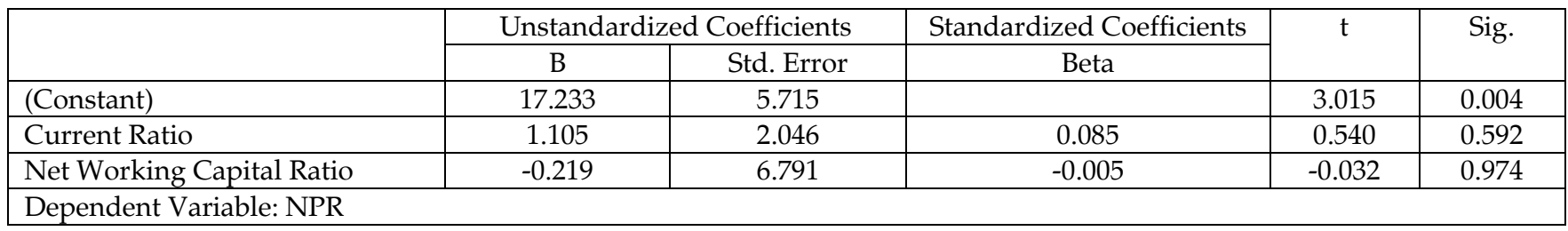

Source: Analysis of Annual Reports of the Sample Banks

Based on the results of coefficients it is visible that the current ratio is positively and insignificantly associated with the net profit ratio as well as the net working capital ratio is negatively and insignificantly associated with the net profit ratio of the sample banks.

MODEL TWO: $\mathrm{ROA}=\alpha+\beta_{1}$ Current Ratio+ $\beta_{2} \mathrm{Net}$ Working Capital Ratio+ $\varepsilon$
This study has conducted multiple regression analysis to test the impact of different indicators of liquidity decision such as current ratio as well as net working capital ratio on return on assets and the null hypothesis Ho2.2: There is no significant impact of the different indicators of liquidity decision on managerial performance represented by the return on assets and the results in this regard are given below:

Table 6: The results of the model summary

\begin{tabular}{|c|c|c|c|c|c|c|c|c|c|}
\hline \multirow[b]{2}{*}{ Model } & \multirow[b]{2}{*}{$\mathrm{R}$} & \multirow[b]{2}{*}{ R Square } & \multirow[b]{2}{*}{$\begin{array}{c}\text { Adjusted R } \\
\text { Square }\end{array}$} & \multirow{2}{*}{$\begin{array}{l}\text { Std. Error of } \\
\text { the Estimate }\end{array}$} & \multicolumn{5}{|c|}{ Change Statistics } \\
\hline & & & & & $\begin{array}{l}\text { R Square } \\
\text { Change }\end{array}$ & $\begin{array}{c}\mathrm{F} \\
\text { Change }\end{array}$ & df1 & df2 & Sig. F Change \\
\hline 02 & 0.060 & 0.004 & -0.039 & 0.375 & 0.004 & 0.085 & 2 & 47 & 0.918 \\
\hline a & Predictor & (Constant & NWCR, CR & & & & & & \\
\hline
\end{tabular}

Source: Analysis of Annual Reports of the Sample Banks 
Above model summary represents the value of $\mathrm{R}$ square is 0.004 that signifies that 0.4 percent of the variability is the dependent variable like return on assets is explained by the independent variables like current ratio and net working capital ratio of the sample banks. In this case the null hypothesis is accepted which means that there is no significant impact of the different indicators of the liquidity decision on the managerial performance as represented by the return on assets.

Table 7: The results of coefficients

\begin{tabular}{|l|c|c|c|c|c|}
\hline & \multicolumn{2}{|c|}{$\begin{array}{c}\text { Unstandardized } \\
\text { Coefficients }\end{array}$} & $\begin{array}{c}\text { Standardized } \\
\text { Coefficients }\end{array}$ & \multirow{2}{*}{ Sig. } & \\
\cline { 2 - 4 } & $\mathrm{B}$ & Std. Error & Beta & & \\
\hline (Constant) & 1.144 & 0.338 & & 3.384 & 0.001 \\
\hline Current Ratio & -0.028 & 0.121 & -0.036 & -0.230 & 0.819 \\
\hline $\begin{array}{l}\text { Net Working } \\
\text { Capital Ratio }\end{array}$ & -0.093 & 0.402 & -0.036 & -0.232 & 0.818 \\
\hline Dependent Variable: ROA \\
\hline
\end{tabular}

Source: Analysis of Annual Reports of the Sample Banks

The results of coefficients show that the current ratio as well net working capital ratio is negatively and insignificantly associated with the return on assets of the sample banks.

MODEL THREE: $\mathrm{ROE}=\alpha+\beta_{1}$ Current Ratio+ $\beta_{2} \mathrm{Net}$ Working Capital Ratio $+\varepsilon$

Multiple regression analysis has been employed in this study to test the impact of the different indicators of liquidity decision such as current ratio as well as net working capital ratio on managerial performance represented by return on equity. The null hypothesis is Ho2.3: There is no significant impact of the different indicators of liquidity decision on managerial performance represented by the return on equity and the results in this regard are presented below:

Table 8: The results of model summary

\begin{tabular}{|c|c|c|c|c|c|c|c|c|c|}
\hline \multirow{2}{*}{ Model } & \multirow[b]{2}{*}{$\mathrm{R}$} & \multirow{2}{*}{$\begin{array}{c}\mathrm{R} \\
\text { Square }\end{array}$} & \multirow{2}{*}{$\begin{array}{l}\text { Adjusted } \\
\text { R Square }\end{array}$} & \multirow{2}{*}{$\begin{array}{l}\text { Std. Error of } \\
\text { the Estimate }\end{array}$} & \multicolumn{5}{|c|}{ Change Statistics } \\
\hline & & & & & R Square Change & F Change & df1 & $\mathrm{df} 2$ & Sig. F Change \\
\hline 03 & 0.296 & 0.088 & 0.049 & 3.750 & 0.088 & 2.265 & 2 & 47 & 0.115 \\
\hline a & Predict & Constant & NCR, CR & & & & & & \\
\hline
\end{tabular}

Source: Analysis of Annual Reports of Sample Banks

The results of model summary reveal that the value of $R$ square is 0.088 which means the 8.8 percentage of the variability is the dependent variable like return on equity is explained by the independent variables like current ratio and net working capital ratio of the sample banks. In this case significance level is 0.115 which means the null hypothesis is accepted. It indicates that there is no significant impact of the different indicators of liquidity decision on managerial performance represented by the return on equity of the sample banks over the study period.

Table 9: The results of coefficients

\begin{tabular}{|l|c|c|c|c|c|}
\hline & \multicolumn{2}{|c|}{$\begin{array}{c}\text { Unstandardized } \\
\text { Coefficients }\end{array}$} & $\begin{array}{c}\text { Standardized } \\
\text { Coefficients }\end{array}$ & \multirow{2}{*}{ Sig. } \\
\cline { 2 - 5 } & $\mathrm{B}$ & Std. Error & Beta & & \\
\hline (Constant) & 17.688 & 3.383 & & 5.228 & 0.000 \\
\hline Current Ratio (CR) & 0.700 & 1.212 & 0.087 & 0.577 & 0.566 \\
\hline $\begin{array}{l}\text { Net Working Capital } \\
\text { Ratio (NWCR) }\end{array}$ & -8.505 & 4.021 & -0.318 & -2.115 & 0.040 \\
\hline \multicolumn{7}{|c|}{ Dependent Variable: ROE } \\
\hline
\end{tabular}

Source: Analysis of Annual Reports of Sample Banks

It is found from the results of coefficients that the current ratio is positively and insignificantly associated with the return on equity but the net working capital ratio is negatively and significantly associated with the return on equity of the sample banks.

MODEL FOUR: ROI $=\alpha+\beta_{1}$ Current Ratio $+\beta_{2} \mathrm{Net}$ Working Capital Ratio $+\varepsilon$

This study has conducted multiple regression analysis to test whether the return on investment of the sample banks is influenced by the different indicators of liquidity decision such as current ratio as well as net working capital ratio and the null hypothesis is Hoz.4: There is no significant impact of the different indicators of liquidity decision on managerial performance represented by the return on investment and the results in this regard are stated below:

Table 10: The results of model summary

\begin{tabular}{|c|c|c|c|c|c|c|c|c|c|}
\hline \multirow{2}{*}{ Model } & \multirow[b]{2}{*}{$\mathrm{R}$} & \multirow{2}{*}{$\begin{array}{c}\mathrm{R} \\
\text { Square }\end{array}$} & \multirow{2}{*}{$\begin{array}{l}\text { Adjusted } \\
\text { R Square }\end{array}$} & \multirow{2}{*}{$\begin{array}{l}\text { Std. Error of } \\
\text { the Estimate }\end{array}$} & \multicolumn{5}{|c|}{ Change Statistics } \\
\hline & & & & & R Square Change & F Change & df1 & $\mathrm{df} 2$ & Sig. F Change \\
\hline 04 & 0.248 & 0.061 & 0.022 & 3.398 & 0.061 & 1.539 & 2 & 47 & 0.225 \\
\hline a. & Predi & tors: $(\mathrm{C}$ & $\tan \mathrm{t}), \mathrm{NW}$ & CR & & & & & \\
\hline
\end{tabular}

Source: Analysis of Annual Reports of Sample Banks

The results of the model summary represent the value of $R$ square which is 0.061 that signifies the 6.1 percentage of the variability is the dependent variable like return on investment is explained by the independent variables like current ratio and net working capital ratio of the sample banks. In this case the null hypothesis is accepted which 
means there is no significant impact of the different indicators of the liquidity decision on managerial performance represented by the return on investment of the sample banks.

Table 11: The results of coefficients

\begin{tabular}{|l|c|c|c|c|c|}
\hline & \multicolumn{2}{|c|}{$\begin{array}{c}\text { Unstandardized } \\
\text { Coefficients }\end{array}$} & $\begin{array}{c}\text { Standardized } \\
\text { Coefficients }\end{array}$ & \multirow{2}{*}{ Sig. } \\
\cline { 2 - 5 } & $\mathrm{B}$ & Std. Error & Beta & & \\
\hline (Constant) & 8.350 & 3.066 & & 2.723 & 0.009 \\
\hline Current Ratio & -1.708 & 1.098 & -0.237 & -1.556 & 0.126 \\
\hline $\begin{array}{l}\text { Net Working } \\
\text { Capital Ratio }\end{array}$ & 4.869 & 3.644 & 0.204 & 1.336 & 0.188 \\
\hline
\end{tabular}

Source: Analysis of Annual Reports of Sample Banks

The results of coefficients state that the current ratio is associated with the return on investment negatively and insignificantly. On the other hand the net working capital ratio is positively and insignificantly associated with the return on investment of the sample banks over the study period.

\section{Results of Correlation Matrix}

In order to report the correlation among the different variables the study has applied the correlation matrix and the results in this regard are presented below:

Table 12: The results of correlation matrix

\begin{tabular}{|c|c|c|c|c|c|c|}
\hline & ROA & $\mathrm{ROE}$ & ROI & NWCR & NPR & CR \\
\hline ROA & 1.000 & & & & & \\
\hline $\mathrm{ROE}$ & $\begin{array}{c}0.844^{* *} \\
0.000\end{array}$ & 1.000 & & & & \\
\hline ROI & $\begin{array}{l}0.208 \\
0.146\end{array}$ & $\begin{array}{l}0.182 \\
0.206\end{array}$ & 1.000 & & & \\
\hline NWCR & $\begin{array}{l}-0.050 \\
0.731\end{array}$ & $\begin{array}{c}-0.285^{*} \\
0.045\end{array}$ & $\begin{array}{l}0.115 \\
0.428\end{array}$ & 1.000 & & \\
\hline NPR & $\begin{array}{c}0.818^{* *} \\
0.000\end{array}$ & $\begin{array}{c}0.614^{* *} \\
0.000\end{array}$ & $\begin{array}{c}0.14 \\
0.326 \\
\end{array}$ & $\begin{array}{l}0.027 \\
0.854\end{array}$ & 1.000 & \\
\hline CR & $\begin{array}{l}-0.050 \\
0.732\end{array}$ & $\begin{array}{l}-0.033 \\
0.822\end{array}$ & $\begin{array}{c}-0.161 \\
0.265\end{array}$ & \begin{tabular}{|c|}
$0.375^{* *}$ \\
0.007
\end{tabular} & $\begin{array}{l}0.083 \\
0.567\end{array}$ & 1.000 \\
\hline \multicolumn{7}{|c|}{${ }^{* *}$ Correlation is significant at the 0.01 level (2-tailed) } \\
\hline
\end{tabular}

Source: Analysis of Annual Reports of Sample Banks

This analysis represents that a positive correlation is existing among the return on equity and the return on assets, net profit ratio and return on assets, net profit ratio and return on equity as well as current ratio and net working capital ratio at $1 \%$ level of significant but there is negative correlation between net working capital ratio and return on equity at $5 \%$ level of significant of the sample banks.

\section{Conclusion And Recommendations}

Liquidity is one of the most important components of corporate business and it has significant role to increase the level of profitability that confirms the good managerial performance of any corporate business. The aim of this study is to investigate the impact of the different indicators of liquidity decision such as current ratio and net working capital ratio on managerial performance surrogated by net profit ratio, return on assets, return on equity as well as return on investment of the sample banks over the study period. The study reported that there is no significant variation of different indicators of liquidity decision as well as managerial performance of the sample banks over the study period. The study also reported that the current ratio as an indicator of liquidity decision is positively and insignificantly associated with net profit ratio as well as return on equity but negatively and insignificantly associated with return on assets as well return on investment. On the other hand, another indicator of liquidity decision namely net working capital ratio is negatively and insignificantly associated with net profit ratio, return on assets as well as return on equity but positively and insignificantly associated with return on investment of the sample banks. In addition, the outcomes of correlation matrix shows that there is positive correlation between return on equity and return on assets, net profit ratio and return on assets, net profit ratio and return on equity as well as current ratio and net working capital ratio at $1 \%$ level of significance but there is negative correlation between net working capital ratio and return on equity at $5 \%$ level of significance of the sample banks over the study period. The banking sector is highly competitive sector among the different sectors of Bangladesh and it has great contribution to enrich the sustainable economic development. In general the role of liquidity as well as profitability is opposite but both are the effective indicators to show the healthy corporate performance. Since the optimum liquidity management increases the profitability trend which is an important indicator of sound managerial performance of any corporate business .So, the banking sector should ensure the effective liquidity management.

\section{REFERENCES}

Adebayo, O. et. al., (2011) "Liquidity Management and Commercial Banks' Profitability in Nigeria", Research Journal of Finance and Accounting, Vol. 2, No. 7/8.

Alrabei, A. M. A., (2013) “Evaluate the Profitability in Commercial Bank Comparative Study of Indian and Jordanian banks", Asian Journal of Finance \& Accounting, Vol. 5, No. 1.

Arfin, M. M. et. al., (2009) “Productivity and Profitability of Prime Finance \& Investment Limited in Bangladesh: An Evaluation", the Islamic University Studies (Part-C), Journal of Faculty of Business Administration (JFBA), Islamic University, Kushtia, Volume 8, No. 02.

Ashraf, M. et. al., (2017) "Liquidity Management and Its Impact on Banks Profitability: A Perspective of Pakistan", International Journal of Business and Management Invention, Volume 6, Issue 5, May.

Begum, R. et. al., (2019) “The Effects of Financing Decisions on the Profitability of Commercial Banks: The Case of Bangladesh", 
Journal of Business Studies, Faculty of Business Studies, Rajshahi University, Vol. 12, No. 1, January-June.

Begum, R. et. al., (2012) "Management Decisions and Univariate Analysis: Effects on Corporate Governance in Bangladesh", Journal of Business Studies, Faculty of Business Studies, University of Rajshahi, Rajshahi, Vol. 3.

Bhunia, A. and Brahma, S. B. (2011) "Importance of Liquidity Management on Profitability", Asian Journal of Business Management 3(2), May.

Das, B. C. et. al., (2015) "Liquidity Management and Profitability Analysis of Private Commercial Banks in Bangladesh", International Journal of Economics, Commerce and Management, United Kingdom, Vol. III, Issue 1, January.

Dr. Md. Abul Hossain, M. A. et. al., (2016) "The Evaluation of Growth Rate of Different Aspects of Commercial Banks in Bangladesh: An Evaluation", International Scholar Journal of Accounting and Finance, Volume-2, No.1.

Dr. Wahiduzzaman Khan, W. et. al., (2020) "The Interactive Approach to Working Capital Knowledge: Survey Evidence", Int. J. Nonlinear Anal. Appl., Volume 11, Special Issue, Winter and Spring.

Lalon, R. M. and Naher, N., (2020) "An Empirical Analysis on Liquidity Management of Commercial Banks in Bangladesh: A Comparative Study between State-Owned and Private Commercial Banks", The Asian Institute of Research Journal of Economics and Business, Vol. 3, No. 1.

Mahmud, K. et. al., (2016) "The Bank-Specific Factors Affecting the Profitability of Commercial Banks in Bangladesh: A Panel Data Analysis", International Journal of Managerial Studies and Research (IJMSR), Volume 4, Issue 7, July.

Maina, K. E., (2018) “Effect of Liquidity Management Strategies on Sustainability of Table Banking Groups in Uasin Gishu Country, Kenya", International Journal of Finance Accounting and Economics (IJFAE), Vol. 1(1), May.

Maqsood, T. et. al., (2016) “Impact of Liquidity Management on Profitability in Banking Sector of Pakistan", International Review of Management and Business Research, Vol. 5, Issue 2.

Neogy, T. K. and and Aishi,A. S., (2017), "Factors Influencing the Earning Capacity of NCBs in Bangladesh: An Evaluation", American Journal of Trade and Policy, Volume 4, Number 2.
Neogy, T. K., (2014) “Evaluation of the Companies' Performance: A Study on Mobile Telecommunication Companies in Bangladesh, American Journal of Trade and Policy", Volume 1, Number 3.

Pandey, I. M., (1991) "Financial Management", Vikas Publishing House Pvt. Ltd., New Delhi.

Parvin, S. et. al., (2019) "Effect of Liquidity and Bank Size on the Profitability of Commercial Banks in Bangladesh", Asian Business Review, Volume 9 Number 1.

Praveen Kumar Donepudi, P. K. et. al., (2020) “Artificial Intelligence and Machine Learning in Treasury Management: A Systematic Literature Review", International Journal of Management, Volume 11, Issue 11, November.

Satyakama, M. and Bhusan, P. B., (2019) "Impact of Liquidity Management on Profitability: An Empirical Analysis in Private Sector Banks of India", Revista ESPACIOS, Vol. 40, No. 30.

Sivathaasan, N. et. al., (2013) "Factors Determining Profitability: A Study of Selected Manufacturing Companies Listed on Colombo Stock Exchange in Sri Lanka", European Journal of Business and Management, Vol. 5, No. 27.

Tahera, K. T., (2014) "A Brief Study over the Liquidity Crisis of the Banking Sector of Bangladesh", Banglavision Research Journal, Vol. 14, No. 1.

Uddin, M. S. and Haque, A., (2016) “The Impacts of Asset Liability Management on Profitability of Selected Banks in Bangladesh", The Bangladesh Accountant, July-September.

Vaish, M. C., ( $8^{\text {th }}$ Updated Edition) "Money, Banking and International Trade", New Age International (P) Limited Publishers, New Delhi.

Ware, E. O., (2015) "Liquidity Management and Its Effect on profitability in a Tough Economy: (A Case of Companies Listed on the Ghana Stock Exchange)", International Journal of Research in Business Studies and Management, Volume 2, Issue 11, November. 


\section{How to cite this article -}

Saha, S. (2021). The Impact of Liquidity Decision on Managerial Performance: Evidence from Private Commercial Banks in Bangladesh. American Journal of Trade and Policy, 8(1), 14-24. https://doi.org/10.18034/ajtp.v8i1.512 